This PDF is a selection from an out-of-print volume from the National Bureau of Economic Research

Volume Title: Tax Policy and the Economy: Volume 4

Volume Author/Editor: Lawrence H. Summers, editor

Volume Publisher: The MIT Press

Volume ISBN: 0-262-19296-9

Volume URL: http://www.nber.org/books/summ90-1

Conference Date: November 14, 1989

Publication Date: January 1990

Chapter Title: Taxation, Corporate Capital Structure, and Financial Distress

Chapter Author: Mark Gertler, R. Glenn Hubbard

Chapter URL: http://www.nber.org/chapters/c11572

Chapter pages in book: (p. $43-72)$ 


\section{TAXATION, CORPORATE CAPITAL STRUCTURE, AND FINANCIAL DISTRESS}

\section{Mark Gertler}

University of Wisconsin and NBER

\section{R. Glenn Hubbard}

Columbia University and NBER

\section{EXECUTIVE SUMMARY}

Is corporate leverage excessive? Is the tax code distorting corporate capital structure decisions in a way that increases the possibility of an economic crisis owing to "financial instability"?

Answering these kinds of questions first requires some precision in terminology. In this paper, we describe the cases for and against the trend toward high leverage, and evaluate the role played by taxation. While provision of proper incentives to managers may in part underlie the trend to the debt, high leverage may in practice be a blunt way to address the problem, and one which opens up the possibility for undue exposure to the risks of financial distress.

Our story takes as given the kinds of managerial incentive problems deemed important by advocates of leverage. We maintain, however, that when a firm is subject to business cycle risk as well as individual

We are grateful to Rosanne Altshuler, Ben Bernanke, Larry Summers, and particlpants at the 1989 NBER conference on Tax Policy and the Economy for helpful comments and suggestions. 
risk, the best financial arrangement is not simple debt, but rather a contract with mixed debt and equity features. That is, the contract should index the principal obligation to aggregate and/or industry-level economic conditions.

We argue that the tax system encourages corporations to absorb more business-cycle risk than they would otherwise. It does so in two respects: first, it provides a relative subsidy to debt finance; second, it restricts debt for tax purposes from indexing the principal to common disturbances. At a deeper level, the issue hinges on the institutional aspects of debt renegotiation. If renegotiation were costless, then debt implicitly would have the equity features relevant for responding to business cycle risk. However, because of the diffuse ownership pattern of much of the newly issued debt and also because of certain legal restrictions, renegotiation is likely to be a costly activity.

\section{INTRODUCTION}

Is corporate leverage excessive? Is the tax code distorting corporate capital structure decisions in a way that increases the possibility of an economic crisis owing to "financial instability"?

Answering these kinds of questions first requires some precision in terminology. We refer to a firm as having "excessive leverage" or a "debt overhang problem" when the magnitude of the principal obligation on the debt it is carrying constrains either the amounts it can invest, produce, or employ. In this regard, the business press regularly records fears of the consequences of high leverage ${ }^{1}$ The sharp rise in corporate debt (and debt-service burdens) over the last six years has sparked this concern. The alarm has also spread among circles in the academic community.

On the other hand, the discussions have rarely been precise about how high debt levels could have bad effects on economic activity. Nor has it been made clear why, if high leverage is so dangerous, the private market economy has generated this kind of situation. Finally, there has been an emerging school of thought, led by Jensen (1986, 1988, 1989), which rejects the idea that current leverage is excessive. Instead, it views the current corporate financial situation as simply an efficient market outcome. The efficiency argument rests on the idea that high leverage may provide lenders with a means to restrict indirectly non-valuemaximizing behavior by corporate managers.

\footnotetext{
${ }^{1}$ See, for example, Anise C. Wallace, "Time for jitters in the junk bond market," New York Times, August 6, 1989.
} 
In this paper, we describe the cases for and against the trend toward high leverage, and evaluate the role played by taxation. While provision of proper incentives to managers may in part underlie the trend to debt, high leverage may in practice be a very blunt way to address the problem, and one which opens up the possibility for undue exposure to the risks of financial distress. We argue that the tax system deserves at least some of the blame for a capital structure that does not optimally shield corporations from the consequences of an economic downturn.

Our story takes as given the existence of the kinds of managerial incentive problems deemed important by the advocates of high leverage. We maintain, however, that when a firm is subject to business-cycle risk as well as individual risk, the best financial arrangement is not simple debt, but rather a contract with mixed debt and equity features. In particular, the arrangement should insulate lenders as much as possible from firm-specific risks but have them share in systemic risks. That is, the contract should index the principal obligation to aggregate and/or industry-level economic conditions. The rough idea is to minimize the impact of a recession on firm net financial positions, as we discuss later in detail.

We proceed to argue that, on the surface, the tax system encourages corporations to absorb more business-cycle risk than they would otherwise. It does so in two respects: First, it provides a relative subsidy to debt finance: second, it restricts debt for tax purposes from indexing the principal to common disturbances. At a deeper level, the issue hinges on the institutional aspects of debt renegotiation. If renegotiation were costless, then debt implicitly would have the equity features relevant for responding to business-cycle risk. However, because of the diffuse ownership pattern of much of the newly issued debt and also because of certain legal restrictions, renegotiation is likely to be a far from costless activity.

The remainder of the paper is organized as follows. Section II summarizes the facts regarding the recent rise in corporate leverage. Section III reviews the main arguments over whether high leverage should be cause for alarm. It describes the benefits of leverage as a corporate control mechanism and the possible costs involved, in terms of raising the possibility of financial distress. This section also addresses the role of taxes in the debate and describes how taxes may distort the capitalstructure decision.

Section IV presents some rough evidence regarding the magnitude of the relative tax subsidy to debt. Whether the "new debt" is easy to renegotiate-that is, whether it is effectively equity-is taken up in Section V. Section VI outlines the issues for tax reform using the guiding 
premise that taxation should not distort corporate capital structure. Finally, Section Vll provides some concluding remarks.

\section{DEBT AND RECENT CORPORATE FINANCING PATTERNS}

The trend to high leverage is relatively new. Over the entire postwar period, equity finance was dominant. For non-financial corporations, retained earnings accounted for roughly 73 percent of funds raised and net new share issues added another 2 percent. Debt provided the balance, divided about equally between private issues (e.g., bank loans and private placements) and public issues (e.g., bonds). Table 1 summanizes this evidence.

Financing patterns altered course duning the 1980s. While corporations continue to rely heavily on retained earnings, they have sharply adjusted the composition of external finance. Most notably, there have been substantial equity repurchases, financed mainly with debt (see, e.g., Shoven, 1987). That is, leverage ratios have risen mainly as the product of corporate capital restructurings. Net new equity issues totaled $-\$ 131$ billion in 1988 , as compared to $+\$ 25$ billion five years earlier.

An important effect of the shift to debt has been a substantial rise in debt-service burdens, and an associated rise in bankruptcies and defaults. Interest payments per dollar of earnings (before interest and taxes) have risen from 16 cents over the postwar period prior to 1970 to 33 cents over the 1970 s to an average of 56 cents over the 1980s. Alternatively, interest payments per dollar of cash flow have increased from about 10 cents in the pre-1970 period to about 35 cents over the 1980 s. This increase in debt-service burdens (documented in Figure 1) has been accompanied by an increase in corporate bankruptcies and liabilities of business failures over the 1980s. While there has been a cyclical pattern of bankruptcies over the postwar period, bankruptcies have been high (relative to postwar standards) throughout the boom following the 1981-1982 recession (see Figure 2). ${ }^{2}$ There is, as well, an impression that larger firms are defaulting on debt obligations (and failing) relative to earlier periods. ${ }^{3}$

${ }^{2}$ This increase in bankruptcies raises the question of why bankruptcy costs would be incurred-that is, why renegotiation of financial contracts has not been more effective. We will return to this point repeatedly.

${ }^{3}$ See, for example, Alison Leigh Cowan, "Rescuing business is now a big business," New York Times, October 5, 1989. 
TABLE 1

Corporate Financing from Internal and External Sources, 1946-1988 (percentage of total sources)

\begin{tabular}{|c|c|c|c|c|}
\hline $\begin{array}{l}\text { Business cycle or } \\
\text { year }\end{array}$ & $\begin{array}{l}\text { Retained } \\
\text { earnings }\end{array}$ & $\begin{array}{c}\text { Private } \\
\text { debt }\end{array}$ & $\begin{array}{l}\text { Corporate } \\
\text { bonds }\end{array}$ & $\begin{array}{c}\text { New equity } \\
\text { issues }\end{array}$ \\
\hline $1945: 4-1949: 4$ & $68.4 \%$ & $16.2 \%$ & $12.4 \%$ & $5.3 \%$ \\
\hline 1949:4-1954:2 & 68.7 & 6.6 & 11.1 & 6.3 \\
\hline 1954:2-1958:2 & 78.4 & 8.2 & 10.9 & 5.4 \\
\hline 1958:2-1961:1 & 79.9 & 8.0 & 9.9 & 4.2 \\
\hline 1961:1-1970:4 & 73.7 & 12.3 & 11.1 & 2.0 \\
\hline 1970:4-1975:1 & 62.0 & 16.8 & 11.2 & 6.5 \\
\hline $1975: 1-1980: 3$ & 74.8 & 6.5 & 10.8 & 2.4 \\
\hline 1980:3-1982:4 & 72.7 & 19.1 & 6.2 & -0.6 \\
\hline $1982: 4-1987: 4$ & 77.6 & 12.3 & 16.0 & -12.8 \\
\hline 1970 & 67.3 & 7.8 & 21.2 & 6.1 \\
\hline 1971 & 65.9 & 4.4 & 16.6 & 10.1 \\
\hline 1972 & 68.0 & 12.0 & 9.6 & 8.6 \\
\hline 1973 & 53.3 & 33.7 & 5.2 & 4.5 \\
\hline 1974 & 60.9 & 17.8 & 13.4 & 2.8 \\
\hline 1975 & 82.1 & -7.4 & 17.9 & 6.5 \\
\hline 1976 & 72.5 & 3.8 & 11.7 & 5.4 \\
\hline 1977 & 74.1 & 13.0 & 10.3 & 1.2 \\
\hline 1978 & 70.7 & 16.0 & 8.2 & -0.0 \\
\hline 1979 & 77.2 & 12.4 & 6.8 & -3.1 \\
\hline 1980 & 72.3 & 7.2 & 10.0 & 4.7 \\
\hline 1981 & 68.2 & 23.7 & 6.5 & -3.3 \\
\hline 1982 & 77.3 & 14.4 & 6.0 & 2.0 \\
\hline 1983 & 74.6 & 10.0 & 4.2 & 6.1 \\
\hline 1984 & 75.6 & 24.5 & 10.4 & -16.8 \\
\hline 1985 & 81.5 & 15.3 & 17.1 & -18.8 \\
\hline 1986 & 73.1 & 10.7 & 24.8 & -16.5 \\
\hline 1987 & 83.0 & 1.2 & 23.5 & -18.0 \\
\hline 1988 & 85.2 & 8.7 & 36.4 & -30.3 \\
\hline
\end{tabular}

Source: Board of Governors of the Federal Reserve System, Flow of Funds Accounts, various issues; and MacKie-Mason (1989).

As suggested, an important factor underlying the trend to debt has been a dramatic rise in corporate restructurings. Prompting the restructurings have been waves of mergers, acquisitions, leveraged buyouts (LBOs), and defense against LBOs. These restructurings have been particularly significant in raising debt-equity ratios. According to First Boston Corporation (1989, p. 27), the average capital structure of an LBO in 1988 included 87 percent debt (divided among bank debt, 53 percent; coupon debt, 20 percent; and deferred-interest obligations) and only 13 percent equity (divided between common, 10 percent; and preferred, 3 


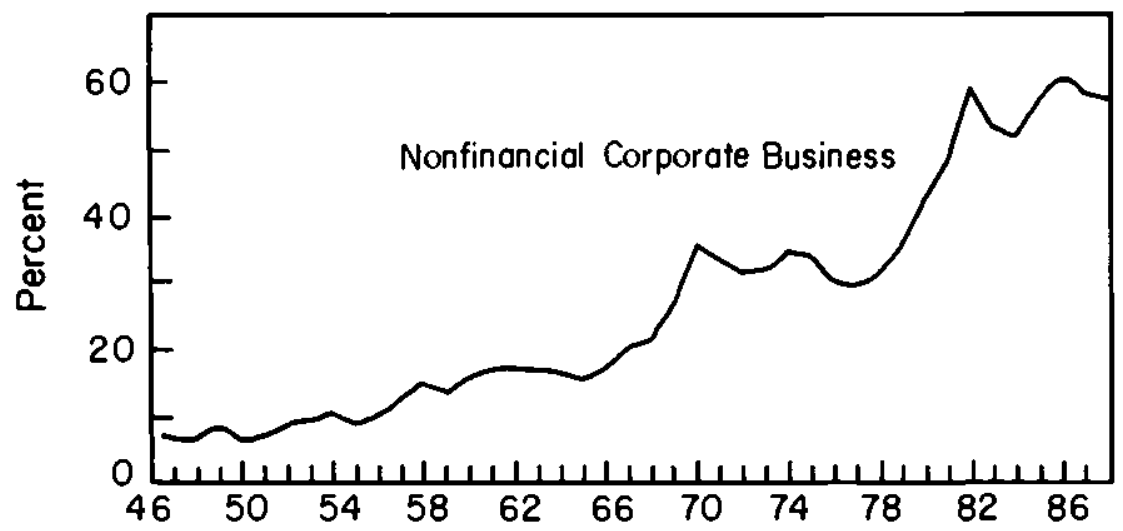

FIGURE 1. Interest payments relative to corporate earnings (1946-1988)

percent). The Office of the Comptroller of the Currency reported that, by the end of 1988 , outstanding LBO debt was roughly $\$ 150-180$ billion. This amounted to about 20 percent of the (book) value of outstanding corporate bonds or over 9 percent of the (book) value of total nonfinancial corporate debt (based on data from the Flow of Funds Accounts). In comparison, from 1978 to 1983, debt emerging from LBO deals was only about $\$ 11$ billion.

The trend to debt, however, encompasses more than just LBOs. Goldman Sachs has estimated that the equity base of U.S. corporations

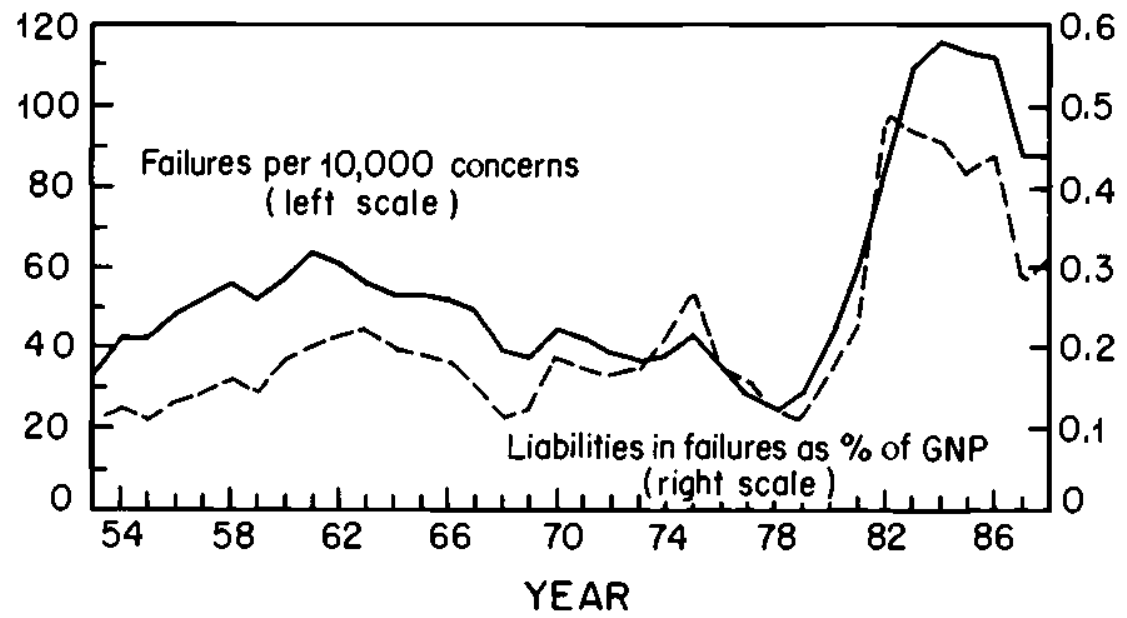

FIGURE 2. Default and bankruptcy rates (1953-1988) 
shrunk by about $\$ 420$ billion between 1982 and 1988 , and that debt supplanted about three-fourths of this reduction. (Financial Market Perspectives, 1988 , p. 5 ).

Another important change in corporate financial policy involved the kind of debt issued. Private debt issues have declined in relative importance. The trend is toward public issues, particularly low grade investments bonds, known popularly as "junk bonds." While junk bonds existed well before the 1980s, widespread use of them has been a relatively sudden event. Seventy percent of outstanding issues (as of the end of 1988) are from the last three years, with 20 percent from 1988 alone (First Boston Corporation, 1989, p. 30).

There is no clear consensus on why the junk bond market grew so dramatically. Many observers, though, tend to agree that the development of the secondary market for junk debt (as part of the general trend toward "securitization") was an important factor. This innovation, it is argued, provided junk bonds with the kind of liquidity needed to induce lenders to absorb them on a large scale. ${ }^{4}$ An added implication was that it made diffuse ownership of a firm's junk debt possible, and even likely. Thus, along with the general rise in leverage, the 1980 s also witnessed a change in the kind of debt issued by corporations-toward debt that involved a more "arms length" relation with bondholders and away from debt, such as bank loans, that permitted a more intimate connection (see Bernanke and Campbell, 1988).

How have junk bonds been faring? After a strong initial performance, total returns on major high-yield funds have fallen significantly in recent years (see Table 2). And for the first half of 1989, the portfolio of highyield issues reported by Moody's Bond Survey (July 17, 1989, p. 5110) had a total return of 5.8 percent versus 11.4 percent for investment-grade bonds-despite the large default premia built into coupon rates.

\section{IMPLICATIONS OF INCREASED CORPORATE LEVERAGE, AND THE ROLE OF TAXATION}

The case in favor of current trends rests on the idea that the private market is well suited to generate the most efficient kind of corporate

\footnotetext{
"The corporate debt "puzzle" is always couched in terms of explaining why current leverage is high. Placed in historical context, an alternative puzzle is why corporate leverage was so low in the 1950 s and 1960 s (see, for example, Taggart, 1985). The idea that financial innovation was important in the recent development of the junk bond market provides (at least part) of a consistent explanation of both phenomena.
} 
TABLE 2

Total Returns, Sample of High-Yield Funds (Year Ending June 30)

\begin{tabular}{lccccc}
\hline Fund & 1989 & 1988 & 1987 & 1986 & 1985 \\
\hline $\begin{array}{l}\text { Dean-Witter } \\
\quad H i g h-Y i e l d\end{array}$ & $4 \%$ & $2 \%$ & $11 \%$ & $23 \%$ & $23 \%$ \\
$\begin{array}{l}\text { Fidelity High Income } \\
\text { Franklin AGE }\end{array}$ & 9 & 5 & 9 & 24 & 29 \\
$\begin{array}{l}\text { Prudential-Bache } \\
\quad \text { High Yield }\end{array}$ & 8 & 7 & 6 & 18 & 25.5 \\
Putnam High Yield & 10 & 8 & 9 & 19.5 & 23 \\
\hline
\end{tabular}

Note: Returns include price appreciation and reinvestment of capital gains and income dividends. Source: Lipper Analytical Services.

organization. The case against argues instead that high leverage exposes the economy inordinately to the risks of a severe business downturn; tax considerations rather than pure efficiency considerations, it is held, primarily drive the movement to debt. In this section we first present both sides of the issue and then conclude by discussing the role of taxes.

\section{IIIA. Benefits of Leverage: Debt as an Incentive Mechanism}

Those who are sanguine about the rise in leverage typically maintain that debt is desirable because it empowers lenders with an indirect means to monitor the activities of managers. The need for some kind of supervision owes to the separation between ownership and management that is characteristic of the traditional corporate structure. As Berle and Means (1932) originally described, a conflict between ownership and management can emerge if it is difficult for the former to observe and evaluate the activities of the latter. In this kind of environment, management's self interest may not always coincide with efficiently operating the firm (i.e., with maximizing firm value).

Jensen and Meckling (1976) formalized this potential for divergence of interests as an "agency problem." Their work and subsequent by others characterized the efficiency losses ("agency costs") that can arise in this environment. An important insight was that financial contracts could be structured to mitigate the problem. Another was that the managerial stake in the enterprise (the managerial equity) was key: the higher the managerial stake, the closer the gap between managerial interests and value maximization, and hence the lower agency costs. Advocates of increased leverage interpret the recent wave of LBOs in this light. The restructurings improved managerial incentives both by converting the 
claims of lenders from equity to debt and by concentrating ownership in the hands of management (i.e., by raising the managerial stake).

But why is high leverage the right course? And perhaps more important, why was the movement to high leverage so recent? In general, the efficient financial structure depends on the exact nature of the conflict between ownership and management. For a wide class of situations, it is optimal to make the managers bear as much of the firm-specific risk as possible, the goal being to have managers internalize the gains from maximizing firm value. ${ }^{5}$ Debt contracts represent an approximate (sometimes exact) way to implement this kind of solution. By promising lenders a fixed stream of payments, the contract effectively ties managerial rewards closely to the performance of the firm. ${ }^{6,7}$

The idea that debt is a way to properly align managerial incentives is at the core of Jensen's (1986) "free cash flow" theory, perhaps the most prominent explanation for the trend to leverage. The story begins with the idea that managers, if given the leeway, will take advantage of outside lenders' inability to ascertain perfectly whether the firm is investing efficiently. Specifically, managers are inclined to squander cash flow by investing for their own aggrandizement in projects with a negative present value. An arrangement where outside lenders hold debt and managers are the residual claimants is a way to minimize this kind of misuse of cash flow. ${ }^{8}$

The Jensen story also offers some additional insight into why the rise in debt occurred so recently, beyond the conventional story that emphasizes innovation in the secondary market for junk debt. It is observed that (i) high cash flow arises primarily in mature industries, and that (ii) the maturing of American industry in the postwar era began only over the last decade. As a result, the argument goes, the widespread need for corporate restructurings is relatively new (see, for example, Blair and Litan, 1989).

This set of arguments contains some loopholes, however. While

${ }^{5}$ Grossman and Hart (1982), for example, show how high debt levels can limit a manager's consumption of prerequisites when firm investment is not easily monitored.

${ }^{6}$ Hall (1988) characterizes these kinds of contracts as "back to the wall," because of the position in which they place management.

${ }^{7}$ One countervailing factor is that the combination of debt finance and limited liability can induce lenders to invest in overly risky projects, if lenders cannot directly monitor investments. In this kind of situation, equity contracts may be optimal.

${ }^{8}$ The value of insiders' stakes for aligning incentives has long been stressed by such practitioners as KKR. Recent accounts have pointed out the role of low insiders' stakes in the failure of the Seaman leveraged buyout. See, for example, Stuart Flack, "See you in bankruptcy court," Forbes, October 16, 1989, pp. 77-80. 
leveraging the firm may be a way to mitigate the kind of agency problem Jensen describes, it is not immediately obvious that it is the best option. If the objective is to make managers bear the residual risk, then it would seem that other practical means are available. One possibility is to adopt a fixed dividend policy with penalties for management if it fails to meet the payment. If these kinds of alternatives are available, ${ }^{9}$ then it appears difficult to explain the debt build-up simply as a response to an emerging agency problem. Tax considerations have likely played a role. If, however, the tax distortion is key, then it is not at all clear that high leverage is the most efficient form of financial organization.

As a matter of theory, high leverage is a very blunt way to align managerial incentives. It works best when most of the variation in cash flow is idiosyncratic to the firm-i.e., when most of the risk is "firmspecific." It works poorly when most of the variation is common across firms, to the extent that debt is costly to renegotiate. The optimal response to the kind of agency problem posed by Jensen insulates lenders as much as possible from the firm-specific risk, but has them share in the common risk. The idea is that managers should be made residual claimants only on the component of profits they can influence-the firmspecific component. For example, managers should not be punished if the firm does poorly during a recession but no worse on average than its competitors. Indeed, to preserve managerial equity-which is valuable for mitigating agency costs-outside lenders should share in the losses to the firm due to an industry-wide or economy-wide recession.

The overall message is that the optimal financial arrangement should link payments to creditors to industry and economy-wide performance (e.g., as would a contract with mixed debt and equity features). Further, because it is desirable to have the outside lenders share in the gains and the losses due to systemic factors, the arrangement is not equivalent to allowing merely for postponement of payment without any adjustment in the present value of the principal obligation. Standard debt contracts do not provide the flexibility needed for sharing of common risks. The

\footnotetext{
${ }^{9}$ Another theoretical possibility is to tie managerial compensation to firm performance, i.e., to use managerial salary rather than capital structure to align incentives. This possibility may be limited in practice, however, by the "business judgment" rule which protects management from liability mistakes of judgment in shareholder challenges in court-as long as management stakes are low (see Gilson, 1986). Yet another alternative in principle is to have the board of directors actively monitor the managers. However, many commentators have lamented the generally weak oversight role provided by outside directors, a role not enhanced by the generally small stake of directors in the firm (see, for example, Shleifer and Vishny, 1988). Similarly, institutional restrictions on banks in the U.S. preclude them from undertaking the kind of extended ongoing monitoring of corporate borrowers that, for example, Japanese banks are free to perform (see Hoshi, Kashyap, and Scharfstein, 1989).
} 
TABLE 3

Issues of High-Yield Debt (percentage of high-yield debt outstanding, December 30, 1988)

\begin{tabular}{lllr}
\hline \multicolumn{1}{c}{ First Boston Study } & \multicolumn{2}{c}{ Drexel Bumham Lambert Study } \\
\hline Containers & $4.8 \%$ & Heavy Industry & $20 \%$ \\
Consumer Manufacturing & 8.0 & Retailing & 14 \\
Chemicals & 2.3 & Leisure & 10 \\
Transportation & 7.3 & Transportation & 8 \\
Media & 8.0 & Consumer Goods & 5 \\
Information and Technology & 2.8 & Media & 11 \\
General Industrial & 7.3 & Banks and Insurance & 7 \\
Food & 6.6 & High-Tech & 5 \\
Energy & 7.8 & Utilities & 4 \\
Consumer Distribution & 11.6 & Miscellaneous & 16 \\
Airlines & 2.1 & & \\
Acquisition & 4.1 & & \\
Utilities & 5.0 & & \\
Metals and Minerals & 2.2 & & \\
Housing & 7.3 & & \\
Health Care & 2.0 & & \\
Gaming and Hotel & 5.9 & & \\
Finance & 3.7 & & \\
Entertainment & 1.3 & & \\
\hline
\end{tabular}

Sources: The categories and calculations are taken from First Boston Corporation $(1989$, p. 20) and from unpublished Drexel Burnham Lambert data reported in David Zigas and Larry Light, "Don't Put Away the Smelling Salts Yet," Business Week, October 2, 1989, pp. 92-93.

advocates of high leverage, however, argue that most debt is easy to renegotiate in practice and, therefore, is implicitly indexed to systemic risks. Whether in fact they are right about renegotiation is perhaps the pivotal question. We will return to this issue frequently.

\section{IIIB. Costs of Leverage: Debt and Financial Stability}

A wide spectrum of economists (e.g., Friedman, 1986; and Kaufman, 1986) have voiced concern that corporate restructurings have exposed the economy unduly to the risk of a financial crisis. Ratios of interest obligations to cash flow are at non-recession record highs (see Bernanke and Campbell, 1988). The general fear expressed is that an otherwise normal business downturn could trigger a large wave of bankruptcies, turning the recession into a severe business downturn. This fear is based on the presumption that highly leveraged transactions have occurred in cyclical as well as acyclical industries.

Indeed, a good fraction of the high-yield debt has been issued in manufacturing, a cyclically sensitive ind ustry. Table 3 reports the break- 
down of high-yield debt (as of the end of 1988) by industry of issue, using data provided by Drexel Burnham Lambert and First Boston Corporation. Based on the First Boston data, depending on how one allocates the components of the "energy" group between manufacturing and extractive activities, about one-half of the stock of high-yield debt is attributable to manufacturing firms. Similarly, the first five categories in the Drexel enumeration (heavy industry, retailing, leisure, transportation, and consumer goods) which are arguably (relatively) cyclical, account for 57 percent of high-yield debt outstanding.

To put the matter in sharper perspective, Bernanke and Campbell considered the counterfactual experiment of imposing the 1974-1975 business recession on a sample of firms with financial conditions corresponding to 1986 data. The sample was drawn from the Compustat file, and therefore consisted primarily of large firms. The simulations implied that a downturn like 1974-1975 would force more than 10 percent of the sampled firms into bankruptcy.

Any argument that high debt levels are dangerous, however, requires qualification. The institutional structure of the economy is critical. Leverage ratios for non-financial corporations are much higher in West Germany and Japan than in the U.S., for example. The critical difference is that, in these countries, the financial institutions that supply debt typically participate in or monitor closely the activities of the firm. (This is particularly true for Japan-see Hoshi, Kashyap, and Scharfstein, 1989-and for Germany - see Berglof, 1988, and Mayer, 1989.) The close connection between the firm and its major creditor facilitates renegotiation. It thus provides (at least some) of the flexibility needed for adjusting to macroeconomic disturbances. It also serves to directly mitigate the agency problem since the lending institution actively monitors the firm. On the other hand, as Jensen (1988) observes, legal restrictions introduced in the wake of the Depression preclude U.S. financial institutions from directly participating in the activities of nonfinancial corporations. The U.S. system of corporate finance is thus closer to one of diffuse ownership with an arms-length relationship between the firm and its creditors. Further, as implied earlier, the substitution of junk bonds for bank loans in recent years is making this characterization increasingly accurate. ${ }^{10}$

It is also true that the quantity of debt a firm issues must be measured against the quality of its underlying collateral, including the managerial

${ }^{10}$ While it is true that banks hold (at least initially) the majority of the senior debt in a highly leveraged restructuring, it is also true that the Comptroller of the Currency has urged them to restrict their holdings to a minimum (see Brancato, 1989). 
equity. Perfectly collateralized debt poses no threat, for example. In a less extreme situation, the collateral position is key to evaluating the dangers the firm may face in the event it cannot meet its current interest obligation (but is otherwise solvent for the long term). A firm with a strong position will find it relatively easy to obtain credit to offset the shortfall in its cash flow. One with a weak position is likely to expenience the costs of financial distress-suspension of credit flows entailing the need for substantial retrenchment in employment and investment. ${ }^{11}$ (For a detailed account of this type of experience, see the description of the Texaco-Pennzoil case in Cutler and Summers, 1988.)

Overall, for the U.S. economy, high debt levels are dangerous to the extent that collateral positions are weak for a significant fraction of corporations and that provisions (either explicit or implicit) do not exist for adjusting the obligations to common risks. ${ }^{12}$ The absence of comprehensive indexing permits destabilizing movements in managenal equity. Forcing the corporation to meet fixed interest obligations in a prolonged recession can deplete managerial equity (to the extent managers are the ultimate residual claimants) which in turn can send the company into financial distress. Similarly, non-contingent debt exposes the economy to the risk of unanticipated wealth redistributions that can have adverse effects. For example, the deflation during the Great Depression wiped out a good fraction of the collateral base of non-financial corporations, which had issued liabilities fixed in nominal terms.

There are some corollary factors also suggesting that high debt levels make the economy particularly vulnerable to a recession. One consideration involves the nature of bankruptcy laws in the U.S. These regulations place severe restrictions on the activities of firms in default, thus adding to the real costs of financial distress (again, see Cutler and Summers, 1988). The cumulative effect of a wave of bankruptcies could greatly exacerbate a downturn. And concern for the potential of widespread defaults does not seem misplaced. Asquith, Mullins, and Wolff (1989) have noted that the default rate on junk debt has been rising, despite the economy's having been in a prolonged expansion; specifically, there has been a rise in cumulative default probabilities for the first several years after issue. In addition, the rated quality of the debt has declined.

${ }^{11}$ Bernanke and Gertler (forthcoming) emphasize that borrower net worth is likely to be important in the renegotiation process.

12 The idea that borrower net worth, rather than debt per se, is fundamentally key to financial stability is present in a number of recent studies. See, for example, Bernanke and Gertler (forthcoming); Calomiris and Hubbard (1990); and the review of studies in Gertler and Hubbard (1988). 
Two other factors involve external effects. First, a kind of "contagion effect" is possible; the default of a large firm or group of large firms can induce panic among lenders, precipitating a liquidity crisis. An example is the near collapse of commercial paper market in the wake of the Penn Central crisis. News of the impending Penn Central default generated fears of defaults by other firms, prompting a flight of funds out of the commercial paper market (see Brimmer, 1988). Similar effects occurred in the municipal bond market after the WHPPS default; and Hirtle (1988) describes how the LTV default (in July 1986) and the outbreak of the Boesky scandal (in November 1986) had adverse consequences on prices and liquidity of junk bonds. ${ }^{13}$ Second, to the extent that there are demand externalities (due, for example, to imperfect competition), the effects of financial distress can spread throughout the economy. In this kind of setting, a downturn in a financially troubled sector can spill over to other sectors (see Cooper and John, 1988, for a discussion of the macroeconomic effects of demand externalities).

\section{IIIC. The Role of Taxes}

As we have noted, (in our view) the cause for concern over high leverage rests on the premise that it limits the ability of corporations to optimally share industry and economy-wide risks with outside lenders. To the extent there is a tax incentive encouraging the use of debt relative to equity, it is relevant to consider how the tax system fits into the overall picture.

ldeally, corporations would like to issue securities they could label as "debt" which permitted the legally required principal obligation to vary, perhaps by introducing contingencies on a set of observable indicators. ln this way, they could collect the tax benefits from debt finance without sacrificing any flexibility in adjusting to common disturbances. More generally, if allowed the option, firms would like to relabel for tax purposes equity as debt. The spirit of the tax code, at least, precludes this kind of activity. The IRS has generally required that any instrument called debt for tax reasons have a payoff which is "sum certain," (e.g." see the review of cases in Bulow, Summers, and Summers, 1989). ${ }^{14}$ Writing a debt contract which either explicitly or implicitly indexes the principal payment to common disturbances violates (at least) the intent of the tax code.

\footnotetext{
${ }^{13}$ Another example, occurring very recently (September 1989), is the response of the highyield debt market to Campeau's troubles.

${ }^{14}$ In principle, the Secretary of the Treasury can define "debt" for tax purposes, as a result of Congress's addition in 1969 of Section 385 to the Internal Revenue Code. The regulations are administratively complex, however.
} 
It is true that IRS accepts as debt securities which permit interest to be deferred. The recently introduced "payment in kind" bonds are an example. However, these securities meet the "sum certain" requirement because they do not explicitly allow for adjustment of the principal obligation. Thus, at least on the surface, they are not useful instruments for sharing common risks.

There is, accordingly, reason to suspect that the current tax system encourages corporations to adopt a financial structure more exposed to common cyclical risks than would be the case in the absence of any subsidy to debt. In Gertler and Hubbard (1989), we sharpen this point. We study a model of firm investment behavior where the kind of incentive problem deemed important by Jensen is present. Because of certain informational asymmetries, firm insiders (say corporate managers and directors) may try to misallocate investment funds on their own behalf. The financial structure is designed to address the incentive problem. However, the tax system introduces a tradeoff between optimally insulating the firm against business cycle risk and minimizing the expected tax burden.

Under a benchmark tax system that treats all kinds of liabilities symmetrically, the optimal financial arrangement insulates the lenders from as much of the idiosyncratic (firm-specific) risk as possible, but has them share in the aggregate risk. This is in keeping with the arguments presented in Section IIIA. The optimal financial arrangement is interpretable as a mixture of "debt" and "equity." Effectively, equity serves as a buffer to business cycle risks; firms may suspend dividend payments in recessions. ${ }^{15}$ This arrangement mitigates the impact of a recession on managerial equity.

Under a tax system that treats debt favorably, firms are induced to issue a smaller fraction of indexed securities (i.e., equity) and thus to absorb more business cycle risk than they would choose in the absence of the distortion. Indeed, if the probability of a recession is sufficiently low, it may be in a firm's interest ex ante to obtain the tax advantage of a high debt-equity ratio at the risk of having a quantity of debt that makes it infeasible to operate in the (ex post) event of a general business downturn. In this situation, because of the large quantity of debt being carried, a recession lowers the net asset position of the firm's insiders to the point where the agency costs are so severe that lenders will no longer

${ }^{15}$ It is interesting to observe that, while insignificant over the postwar period, equity issues were an important form of corporate finance prior to the Depression, accounting for more than 15 percent of funds raised during the 1901-1929 period (Taggart, 1985). It is possible that greater cyclical movements (common risks) contributed to the increased reliance on equity finance over that period. 
supply credit. The tax system thus encourages the firm to risk the possibility of having a debt-overhang problem in a recession. ${ }^{16}$

We also consider the implications of permitting the principal obligation on debt to be renegotiable. Having (costlessly) renegotiable debt makes debt effectively like equity and thus completely unravels the effect of the tax distortion. The outcome is exactly equivalent to the case of symmetric tax treatment of debt and equity.

Two basic questions emerge directly relevant to public policy. First, how large is the tax subsidy to corporate debt? Second, is debt, particularly the "new" kind of debt, easily renegotiable and thus effectively "equity in drag." If the latter is true then the only public policy question is whether the effective reduction in the corporate cost of capital is desirable. If it is not true, and if the debt subsidy is significant, then it is conceivable that the tax system is encouraging an overly fragile corporate structure.

We address these questions in the next two sections. Section IV discusses the magnitude of the tax subsidy, while Section $\mathrm{V}$ takes up the issue of renegotiation.

\section{THE TAX SUBSIDY TO DEBT}

In this section we examine the relative tax treatment of debt versus equity. A major point we emphasize is that it is important to distinguish between the incentives provided for using leverage to finance new investments versus using it to repurchase equity. We also try to evaluate recent changes in the tax code in this light.

The relative subsidy to debt is a long-standing feature of the U.S. tax code. It is in part an outcome of the classical system of income taxation under which the incomes to corporations and to the individuals who supply them with funds are taxed separately. Under this kind of system, the effective tax rate on a security depends on its treatment both at the corporate level and the personal level. There are three important "wedges." First, corporations may deduct interest paid to bondholders, but cannot deduct dividends paid to shareholders. Second, individuals must pay taxes on interest as it accrues, as opposed to when it is actually received, but they need to pay taxes on income from stocks (dividends and capital gains) only when it is realized. Third, capital gains have been historically taxed at rates below those on ordinary income.

\footnotetext{
${ }^{16}$ We do not mean to suggest that tax distortions are the only reason financial contracts may not be properly indexed to aggregates. It is, for example, a longstanding puzzle as to why debt contracts are not indexed to the price level. Factors such as the inability to find good indices are probably also important to explaining incomplete indexing.
} 
With respect to choosing between debt and equity to finance new investments, it is relevant to compare the total (corporate and individual) tax burden on each kind of security. The interest deduction at the corporate level, of course, provides a major tax break for using debt. Conversely, the low capital gains rate at the personal level works in favor of equity. In this regard, recent tax changes have had a mixed effect. The 1981 tax act reduced capital gains along with individual tax rates (maintaining the level of the corporate tax rate), while the 1986 act raised them. Specifically, it called for treating realized capital gains as ordinary income (though preserving the advantage of deferral).

For financing new investment, the subsidy to debt finance is

$$
t_{c}+\left(1-t_{c}\right) t_{p}^{e}-t_{p}^{d}
$$

where $t_{c}$, $t_{p}^{e}$, and $t_{p}^{d}$ represent, respectively, effective tax rates on corporate income, and equity and debt income at the individual level. The first two terms represent the taxes paid on returns from an equity-financed investment; the last reflects the tax paid on a return from a debt-financed project (untaxed at the corporate level). The effective tax rate on equity depends on assumptions about the mix of returns between dividends and capital gains as well as the deferral advantage of capital gains.

The effective corporate tax rate will in general be less than the statutory rate because of the tax-loss carryforwards. Altshuler and Auerbach (1990) calculate that during the early 1980s, the effective tax rate was about 32 percent, as opposed to the statutory rate of 46 percent. Gordon and MacKie-Mason (1989) estimate the effective tax rate to be about 29 percent in 1988, as opposed to the statutory rate of 34 percent. Using Poterba's (1989) estimate of $t_{p}^{d}$, they estimate the tax subsidy to debt (implied by the expression above) to be 19.9 percent just prior to the Tax Reform Act of 1986, and 22.4 percent in 1988. Alternatively, using the effective tax rates on interest and equity-return recipients calculated in Table 4, the spread between equity and debt tax rates is larger $(30.2$ percent). ${ }^{17}$ (Both calculations assume that the effective capital gains rate is one-fourth of the statutory rate because of the effects of deferral and stepped-up basis at death; see Feldstein, Dicks-Mireaux, and Poterba, 1983.)

The tax considerations involved for deciding to restructure are slightly different from those for financing new investments. Because in this instance leverage is being used to repurchase shares, the net tax cost of

${ }^{17}$ In addition, the Deficit Reduction Act of 1984, which eliminated withholding taxes on newly issued corporate bonds, provided incentives for foreigners to increase their holdings of U.S. corporate bonds. 
TABLE 4

Effective Tax Rates for Recipients of Debt and Equity Payments

\begin{tabular}{|c|c|c|c|}
\hline \multirow[b]{2}{*}{ Taxpayer category } & \multirow[b]{2}{*}{$\begin{array}{c}1988 \\
\text { Tax rate }\end{array}$} & \multicolumn{2}{|c|}{ Percentage of total } \\
\hline & & $\begin{array}{l}\text { Interest } \\
\text { receipts } \\
(1988)\end{array}$ & $\begin{array}{c}\text { Equity } \\
\text { holdings } \\
(1988)\end{array}$ \\
\hline $\begin{array}{l}\text { Households (untaxed) } \\
\text { Households (taxed) }\end{array}$ & $\begin{array}{l}0 \% \\
28\end{array}$ & $\begin{array}{l}2.8 \% \\
4.8\end{array}$ & {$[62.0 \%]$} \\
\hline Foreigners & 0 & 12.7 & 5.4 \\
\hline Commercial Banks & 15 & 5.7 & 0 \\
\hline Savings and Loans & 18 & 3.0 & 0 \\
\hline Mutual Savings Banks & 6 & 1.1 & 0.2 \\
\hline Insurance Companies & 20 & 35.7 & 5.1 \\
\hline Private Pensions & 0 & 12.7 & 15.5 \\
\hline $\begin{array}{l}\text { State and Local Government } \\
\text { Retirement Funds }\end{array}$ & 0 & 10.9 & 6.2 \\
\hline $\begin{array}{l}\text { Mutual Funds } \\
\text { Securities Brokers and Dealers }\end{array}$ & $\begin{array}{l}28 \\
34\end{array}$ & 4.4 & 5.2 \\
\hline Securities Brokers and Dealers & 34 & 1.5 & 0.7 \\
\hline Weighted-Average & & $7.3 \%$ & $19.9 \%$ \\
\hline
\end{tabular}

Sources: Tax rates are taken from Tax Analysts (1986). Interest receipts data are from Summers (1989). Relative ownership of corporate equity in 1988, weighted by the market value of holdings, are obtained from Flow of Funds data published by the Board of Governors of the Federal Reserve System.

issuing debt depends positively on the effective tax on distributions to the existing equity holders, who receive capital gains in process. That is, while a low capital gains rate reduces the subsidy to using debt to finance new capital investment, at the same time it encourages replacing existing equity with debt.

Both corporate and individual tax rates declined after the Tax Reform Act of 1986. In addition, because the statutory capital gains tax rate has been (relatively) high since 1986, it might appear that tax considerations provided little incentive for the mass of corporate restructurings that have occurred since then. On the contrary, even abstracting from deferral advantages, the average effective capital gains tax rate is much lower than the individual income tax rate. This is because capital gains accrue in part to institutional and foreign investors paying lower tax rates. For example, the effective tax rate is zero for pension funds and foreign investors. ${ }^{18}$ Moreover, the fraction of equity held by zero-tax investors

\footnotetext{
18 The tax rate is "effectively zero" for pension funds, since taxes are pald ultimately by beneficiarles, who are able to defer the obligation, and the advantage of deferral is still quilte substantial. Forelgn Investors also effectively face a zero rate. U.S. capital gains taxes are not levied on foreigners, and withholding taxes on dividends are low for most investors from countries with tax treaties with the United States.
} 
(foreign investors and private and state and local government pension funds) has grown from 12.1 percent in 1970 to 22.1 percent in 1979 to 27.1 percent in 1988 . In summary, since interest payments are deductible at the corporate rate, there are still tax incentives underlying the recent switch from debt to equity.

While the tax system encourages the use of leverage, it is unlikely that tax considerations alone are responsible for the current surge in debt. It is hard to pinpoint any recent changes in the tax code that could have promoted a major shift to leverage. A more plausible scenario is that innovations in the junk bond market described earlier (primarily the development of the secondary market) opened up the possibility for corporations to exploit the tax advantage on a much wider scale than was ever possible before. ${ }^{19}$

\section{IS DEBT REALLY DEBT?}

As we have emphasized throughout, a critical question is whether junk bonds are easily renegotiated in the midst of industry-wide or economywide recessions. The claim that junk bonds have the pertinent equitylike features center on five propositions:

(i) Junk bonds are more closely held than traditional debt, which facilitates renegotiation.

(ii) The new instruments have fewer restrictions and covenants than traditional private placements, which facilitates trade on a secondary market.

(iii) Original-issue-discount and payment-in-kind obligations permit the issuer to skip cash payments in some periods.

(iv) Exchange offers of securities can forestall default and bankruptcy in periods of financial distress. Further, incentives are strong to complete these transactions because highly leveraged firms are likely to be valuable ongoing concerns, at least relative to traditional firms in financial distress.

(v) For reputational considerations, firms like Drexel Burnham Lambert or KKR have a strong incentive to guarantee liquidity in the market.

We address each of these points in turn.

${ }^{19}$ Highly leveraged transactions involving unsecured debt have long been common in the financing of small and medium-sized corporations. Traditionally, such transactions consisted of secured debt ( 60 percent), equity ( 10 percent), with the balance handled largely through private placements with insurance firms. This market was not large enough to finance large-scale unsecured debt issues necessary to wage war for the control of large corporations (see Perry and Taggart, 1988). 
With respect to the first point, the opposite is probably true; holdings of junk bonds are more dispersed than holdings of traditional debt, raising instead of lowering - all other things being equal-the costs of renegotiation. Over the past decade, non-financial corporations have steadily relied less on bank credit and more on funds obtained from bond markets (e.g., insurance companies, pension funds, and foreigners). Bank loans provided 44 percent of debt funds raised by nonfinancial corporations in 1979 and only 21 percent in 1988. Corporate bonds provided just over 25 percent in 1979, and 50 percent in 1988 . Bonds used in highly leveraged transactions have in part replaced equity, bank loans, and private placements. While traditional debt was indeed closely held, the same is unlikely to be true for the new debt. The process of securitizing-critical to the growth of the market-makes possible widely diffuse holdings; see Bernanke and Campbell (1988) for related arguments.

lndependent studies by Drexel Burnham Lambert and Hirtle (1988) at the Federal Reserve Bank of New York confirm these points. Breakdowns of high-yield debt holdings by investor class are reported in Table 5. For example, Hirtle estimates that in 1987, 66 percent of junk bond holdings were in the hands of mutual funds ( 25 percent), pension funds ( 10 percent), and insurance companies ( 31 percent). The balance

\section{TABLE 5}

\section{Holdings of High-Yield Debt by Investor Class}

\begin{tabular}{lccc}
\hline & \multicolumn{2}{c}{$\begin{array}{l}\text { Holdings as a Percentage of } \\
\text { high-yield debt outstanding }\end{array}$} & \\
\cline { 2 - 4 } & $\begin{array}{c}\text { Drexel } \\
\text { Institution or group }\end{array}$ & $\begin{array}{c}\text { New York Fed } \\
(1986)\end{array}$ & $\begin{array}{c}\text { Drexel } \\
(1988)\end{array}$ \\
\hline Mutual funds & $32 \%$ & $25 \%$ & $30 \%$ \\
Insurance companies & 30 & 31 & 30 \\
Pension funds & 10 & 10 & 15 \\
Individuals & 10 & 10 & 5 \\
Savings and Loan & 7 & 6 & 7 \\
$\quad$ Institutions & 3 & & 9 \\
Foreigners & 3 & 18 & 3 \\
Domestic corporations & 1 & & 1 \\
Securities dealers & 4 & & 0 \\
Others & & & \\
\hline
\end{tabular}

Sources: Drexel Burnham Lambert data for 1986 are taken from Report on High Yield Bonds, General Accounting Office, February 29, 1988. The Federal Reserve Bank of New York data for 1987 are taken from Hirtle (1988). Drexel Burnham Lambert data (as of December 31, 1988) were reported in David Zigas and Larry Light, "Don't Put Away the Smelling Salts Yet," Business Week, October 2, 1989, pp. 9293. 
was distributed among individuals (10 percent), savings and loan institutions (6 percent), and other investors (including foreign investors and domestic corporations-18 percent). Further, in addition to complications introduced by dispersion of ownership, "prudent man" rules (under ERISA) governing pension funds and institutions managing pension accounts (see Warshawsky, 1988) may restrict the ability of many institutions to renegotiate.

With respect to the second point, it is no longer true that high-yield debt avoids the restrictions common in traditional private placements. For example, First Boston Corporation (1989, p. 35) reports:

the market appears to be coming full circle, back toward the stringent indenture packages of the private placement market. While earlier issues of public high yield securities found that they could trade the liquidity of the public high yield market for the tighter indentures demanded in the private market, many of the more recent issues include covenant packages rivaling those provided in the private market.

Specifically, the First Boston study notes that as late as 1986, most major deals contained no restrictions on additional debt; by 1987, the major issues reviewed all contained varying degrees of protection against incremental borrowing, thus impeding the ability to renegotiate. This pattern is expected to continue. Other relevant restrictions related to changes in corporate control ("poison puts"), requirements of net worth maintenance, and limitations on certain payments, mergers and consolidations, and asset sales.

The recent issue of senior subordinated notes by Playtex (due December 15,1988 ) well illustrates the new restrictions. Though the firm is credited with having a stable market position and consistent operating earnings, Moody's assigned the issue a B2 rating out of concern over interest coverage. The Moody's review indicated a number of covenants relating to changes in control, limitations on debt and dividend payments, and net worth maintenance (Moody's Bond Survey, December 19, 1988, pp. 4212-14). The review also expressed concern about the possible effects of leverage on future invstment decisions:

.. A significant risk for Playtex is that it may not have the financial strength to support the marketing and manufacturing programs necessary to build higher sales volume. (p. 4213)

The third point pertains to the newly introduced debt instruments which permit corporations some flexibility in meeting their interest obli- 
gations. There are several kinds. "Original issue discount" bonds defer either all ("zerofix") or part ("split coupon") of the interest payments until maturity. These bonds are growing in popularity: fully 25 percent of new high yield issues in 1988 were original issue discount bonds, and they accounted for 14.4 percent of the stock of high-yield debt and 6 percent of total outstanding corporate debt obligations (First Boston Corporation, 1989, p. 23). "Payment in kind" (PIK) obligations allow the issuer to pay interest in cash or in additional securities (which would be valued at par). These kinds of contracts permit the firm to defer cash payments in periods of distress.

Like equity, these new instruments permit corporations to overcome temporary liquidity problems. However, unlike equity, they do not allow firms to share the risks of systemic disturbances with outside lenders. Both types of instruments, as well as traditional debt, meet the "sum certain" requirement imposed by the IRS. That is, while they permit deferral of interest, they do not allow for costless adjustment of the principal obligation. Thus, they do not permit the kind of indexing necessary to insulate corporations from systemic nisks (as described in Section lllA).

One recent illustration of this point relates to the securities issued in the 1987 purchase of SCl TV by Kohlberg, Kravis, Roberts. The accumulating debt-as cash interest payments are omitted by the financially strapped deal-will grow from $\$ 200$ million in PlKs in October 1987 to $\$ 310$ million in October 1990 . The result according to one investment manager: "You have a 5-pound bag and 10 pounds of garbage" (see "How KKR Stubbed lts Toe," Business Week, August 7, 1989, p. 56). Other examples have emerged recently, as well. ${ }^{20}$

lt is worth emphasizing that the IRS appears determined to prevent firms from simply relabeling equity as debt; in particular, it has taken the sum certain requirement seriously. For example, in 1982, Goldman Sachs attempted to introduce Adjustable Rate Convertible Notes, which allowed for variable payments to bondholders (based on explicit contin-

\footnotetext{
${ }^{20}$ Concern has been expressed that PIK bonds do not adjust the principal obligations. For example:
}

The wide interest in troubled businesses comes as many companies that loaded up on tax-favored debt capital in recent years are ruing their boundless optimism. Even when a company's income did not justify the debt load, Wall Street's financial engineers often found ways of deferring the out-of-pocket costs.

Known as pay-in-kind securities, increasing-rate notes, or zero-coupon bonds, these exotic inventions cleverly conserve cash in a deal's early years. But the borrower faces a balloon payment on a future day of reckoning. (In Alison Leigh Cowan, "Rescuing businesses is now a big business," New York Times, October 5, 1989.) 
TABLE 6

Exchange Offers and Subsequent Defaults (sample of high-yield bonds, by year of issue)

\begin{tabular}{lccc}
\hline $\begin{array}{l}\text { Issue } \\
\text { year }\end{array}$ & $\begin{array}{c}\text { Cumulative default } \\
\text { percentage (of } \\
\text { dollar amount of issues) }\end{array}$ & $\begin{array}{c}\text { Percentage of total } \\
\text { issues exchanged } \\
\text { (\$ amount) }\end{array}$ & $\begin{array}{c}\text { Percentage of total issues } \\
\text { exchanged with subsequent } \\
\text { default (\$ amount) }\end{array}$ \\
\hline 1977 & $33.92 \%$ & $30.95 \%$ & $49.11 \%$ \\
1978 & 34.36 & 20.11 & 55.17 \\
1979 & 24.70 & 4.43 & 75.00 \\
1980 & 27.56 & 17.33 & 64.62 \\
1981 & 20.97 & 29.44 & 17.81 \\
1982 & 25.94 & 7.23 & 88.89 \\
1983 & 19.21 & 13.66 & 44.51 \\
1984 & 9.38 & 4.80 & 0.00 \\
1985 & 3.53 & 3.25 & 0.00 \\
1986 & 8.14 & 1.55 & 31.25 \\
Totals & $10.66 \%$ & $5.19 \%$ & $32.81 \%$ \\
\hline
\end{tabular}

Source: Tabulations are based on the study of original-issue high-yield bonds in Asquith, Mullins, and Wolff (1989, Tables, 2, 6, and 7). Cumulative percentages are through December 31, 1988. Defaults refer to bankruptcy filing, formal declaration by the trustee of a bond, or a missed coupon payment. Exchange offers do not include security transactions after default or bankruptcy.

gencies). However, the IRS disallowed the contracts in 1983 for failing to meet the sum certain principle.

Regarding point four, "exchange offers" of securities-the typical mechanism for out-of-bankruptcy renegotiation-are problematic with multiple creditor interests. Such offers are voluntary, raising a "freerider" problem: debtholders not participating in the exchange of securities may see the market value of their securities subsequently rise, lowering the desire of a given debtholder to participate.

Moreover, historically, completed exchange offers have not provided sufficient breathing room for distressed companies to rebound (First Boston Corporation, 1988, pp. 35-36; 1989, p. 46), and investors have experienced similar losses in distressed exchange offers as in defaults (Asquith, Mullins, and Wolff, 1989). These losses have over the past decade averaged 50.05 percent of principal (First Boston Corporation, 1989, p. 45). Table 6, which uses tabulations from Asquith, Mullins, and Wolff (1989), shows that while exchange offers are not infrequently used, their ability to avoid default is rare.

Another consideration is that the availability of renegotiation under Chapter $\mathbf{1 1}$ may provide firms with an attractive alternative to out-ofbankruptcy renegotiation. Under Chapter 11, equity holders and managers have a more significant claim on the enterprise than they would, say, in liquidation. Further, the uniform voting (by creditors) required 
under Chapter 11 avoids many of the free-rider problems associated with voluntary renegotiation. Out-of-bankruptcy arrangements are not a perfect substitute here, because only Chapter 11 procedures avoid the tendency for bilateral renegotiations. Nor are formal covenants in (publicly issued) bonds. The Trust Indenture Act forbids the inclusion of voting procedures for bondholders to adjust principal and/or interest payments (see Jackson, 1986; or Roe, 1987, for a discussion). Hence, in periods of distress both debtors and creditors may prefer filing for Chapter 11 to voluntary renegotiation; this sentiment is echoed in First Boston Corporation (1989, p. 43).

It is probably true that incentives to complete exchange offers are stronger for highly leveraged firms than for traditional firms, since the value of the underlying assets in the wake of default or bankruptcy is likely to be greater, holding everything else constant. Nonetheless, the weight of (informal) evidence suggests that the frictions owing to the free-rider and institutional considerations mentioned above remain present in the exchange offer process. It is probably also still the case that equity or closely held debt provides better insulation against common risks.

Finally, is it the case that the investment banks and deal makers that have a major stake in the ongoing use of junk bonds will actively intervene to ensure the smooth functioning of the market? Indeed, to date, investment banks such as Drexel Burnham Lambert have played an important role in providing the needed liquidity by actively participating in the secondary market. In our view, these private institutions can perform "lender of last resort" functions when defaults (or near defaults) are relatively isolated incidents. However, it is unlikely that they have the resources to intervene in the midst of a wave of defaults owing to some kind of systemic disturbance. Indeed, the popular perception is that the liquidity of the junk bond market has been drying up as the frequency of defaults has been rising. ${ }^{21}$

\section{THE AGENDA FOR TAX REFORM}

We now consider possible reforms which would mitigate the impact of the tax system on corporate capital structure (see also Auerbach, 1989).

One possibility is complete integration of corporate and individual income taxes; this would, of course, eliminate the need to define debt and equity for tax purposes. It would, however, aIso entail windfalls to

${ }^{21}$ See, for example, Anise C. Wallace, "Time for jitters in the junk bond market," New York Times, August 6, 1989. 
existing equityholders, and eliminate any revenue from investments by foreign shareholders and domestic tax-exempt shareholders. Another possibility is to remove the tax deductibility of interest, which would place debt and equity on a more equal footing. This action, however, would raise the cost of capital to corporations; and it would also confer an advantage on foreign investors in the market for corporate control in the U.S. The latter is true because foreign investors avoid capital gains taxes in the U.S. and may not pay taxes on their U.S. income in their home country (if they are subject to a territorial tax system).

To the extent that corporate-level taxes on capital income are to be maintained, a corporate cash-flow tax provides an alternative way to minimize the differential treatment of debt and equity. ${ }^{22}$ Abstracting from the tax treatment of financial institutions, the tax base would be the difference between gross income (receipts less costs of goods sold) and investment expenses. That is, depreciation deductions are replaced by expensing investment, and interest deductions are removed. There is thus no marginal effect of corporate taxation on investment decisions. Nor is there any distinction between returns to existing and new equity, since the tax is effectively on distributions less new equity issues.

The corporate cash-flow tax does not, however, remove all distinctions between debt and equity for tax purposes (see the discussion in Auerbach, 1989). In principle, since the cash-flow tax imposes a zero marginal tax on both debt and equity, the marginal effects of the tax are akin to those of a true income tax in which there are deductions for real returns to both debt and equity. Taking corporate and individual levels of taxation into account, equity returns would have a lower effective tax rate than debt under a cash-flow tax, since interest payments would continue to be taxable for individuals. The transition problems associated with converting to a cash-flow tax are also significant (see the discussion in King, 1986).

\section{CONCLUDING REMARKS}

Assessing whether corporate leverage is "too high" requires some kind of metric. We propose one, using an approach that stresses the role of financial contracts in aligning managerial incentives. We argue that, when common as well as idiosyncratic disturbances are important to firm profitability, the optimal financial arrangement involves a mixture of debt and equity. The arrangement is also equivalent to one with debt

22 See, for example, Institute for Fiscal Studies (1978), King (1986), Feldstein (1989), and Hubbard (1989). 
that has provisions allowing for adjustment of the principal in response to industry-wide or economy-wide disturbances. The idea is to have outside lenders share the systemic risks in order to insure the firm's financial position, and therefore its creditworthiness, against fluctuations in general business conditions. Our measure of excessive leverage is therefore (roughly speaking) a measure of the degree to which financial contracts are not optimally indexed to cyclical disturbances.

In this regard, distortions contributed by the tax system may be an important factor in creating a situation of excessive leverage. The point is somewhat more subtle than the usual argument that the relative tax subsidy increases the level of debt, thereby increasing the risk of default. The traditional literature, we think, misses the significance of the distinction between idiosyncratic and common risks. As stressed earlier, when only firm-specific risks are important, it is conceivable that pure debt financing is desirable, despite the possibility of costly default and independent of tax considerations. Once common risks are present, however, the tax system introduces a tension. In particular, the authorities who define debt for tax purposes make difficult the kind of indexing provisions desirable for insuring against common risks. This introduces an important tradeoff in the capital structure decision-the benefits from additional debt of the expected tax subsidy versus the costs of having reduced flexibility in adjusting obligations to creditors in the event of an industry-wide or economy-wide recession. We argue further that because junk bonds are costly to renegotiate in practice, it is unlikely that optimal indexing is implicitly present.

We are left with some clear but difficult policy choices. An important problem with the current system is that it seeks to classify particular forms of financial contracts for tax purposes, and thereby interferes with the efficient choice of capital structure. Integrating corporate and individual tax systems or instituting a corporate cash flow tax may be desirable because either avoids the need for this kind of classification, and therefore mitigates the distortion. However, instituting such reforms also requires addressing possible revenue considerations and problems of transition. Nonetheless, discussions of these issues should figure prominently in the debate over corporate leverage.

\section{REFERENCES}

Altshuler, Rosanne and Alan J. Auerbach. 1990. The significance of tax law asymmetries: An empirical investigation. Quarterly Journal of Economics 105: 61-86 (February).

Asquith, Paul, David W. Mullins, Jr., and Eric D. Wolff. 1989. Original issue 
high yield bonds: aging analyses of defaults, exchanges, and calls. Journal of Finance 44: 923-52 (September).

Auerbach, Alan J. 1989. Debt, equity, and the taxation of corporate cash flows. University of Pennsylvania. Mimeo.

Berglof, Erik. 1988. Capital structure as a mechanism of control: A comparison of financial systems. Discussion paper No. 48, Program in Law and Economics, Harvard Law School (December).

Berle, Adolph and Gardiner Means. 1932. The Modern Corporation and Private Property. New York: Macmillan.

Bernanke, Ben and John Y. Campbell. 1988. Is there a corporate debt crisis? Brookings Papers on Economic Activity. Washington, D.C., The Brookings Institution, vol. 1: 83-125.

Bernanke, Ben and Mark Gertler. Forthcoming. Financial fragility and economic performance. Quarterly Journal of Economics 105: 87-114.

Blair, Margaret M. and Robert E. Litan. 1989. Explaining corporate leverage in the eighties. Washington, D.C., The Brookings Institution. Mimeo.

Brancato, Carolyn K. 1989. Leveraged buyouts and the pot of gold: 1989 update. A Report Prepared for the Use of the Subcommittee on Oversight and Investigations of the Committee on Energy and Commerce, U.S. House of Representatives (July).

Brimmer, Andrew. 1989. Central banking and systemic risks in capital markets. Journal of Economic Perspectives 3: 3-16 (Spring).

Bulow, Jeremy I., Lawrence H. Summers, and Victoria P. Summers. 1989. Distinguishing debt and equity in the junk bond era. Harvard University. Mimeo.

Calomiris, Charles W. and R. Glenn Hubbard. 1990. Internal finance, firm heterogeneity, and credit rationing. Economic Journal 100 (March).

Cooper, Russell and Andrew John. 1988. Coordinating coordination failures in Keynesian models. Quarterly Journal of Economics 103: 441-64 (August).

Cutler, David M. and Lawrence H. Summers. 1988. The costs of conflict resolution and financial distress: evidence from the Texaco-Pennzoil litigation. Rand Journal of Economics 19: 157-72 (Summer).

Feldstein, Martin. 1989. Excess debt and unbalanced investment: The case for a cashflow business tax. Testimony before the Committee on Ways and Means, United States House of Representatives, January 31.

Feldstein, Martin, Louis L. D. Dicks-Mireaux, and James M. Poterba. 1983. The effective tax rate and the pre-tax rate of return. Journal of Public Economics 21: 129-53.

First Boston Corporation. High Yield Handbook. Various issues.

Friedman, Benjamin M. 1986. Increasing indebtedness and financial instability in the United States. In Debt, Financial Stability and Public Policy. Federal Reserve Bank of Kansas City.

Friedman, Benjamin M. 1989. Views on the likelihood of financial crisis. In Reducing the Risk of Economic Crisis. Martin Feldstein, ed. Chicago: University of Chicago Press, (forthcoming).

Gertler, Mark and R. Glenn Hubbard. 1988. Financial factors in business fluctuations. In Financial Market Volatility. Federal Reserve Bank of Kansas City.

Gertler, Mark and R. Glenn Hubbard. 1989. Corporate taxation, capital structure, and aggregate fluctuations. Columbia University. Mimeo.

Gertner, Robert and David Scharfstein. 1989. The effects of reorganization law on investment efficiency. MIT Mimeo. May. 
Gilson, Ronald J. 1986. The Law and Finance of Corporate Acquisitions. Mineola, New York: The Foundation Press.

Gordon, Roger H. and Jeffrey K. MacKie-Mason. 1989. Effects of the Tax Reform Act of 1986 on corporate financial policy and organization form. University of Michigan. Mimeo. September.

Grossman, Sanford and Oliver Hart, 1982. Corporate financial structure and managenal incentives. In The Economics of Information and Uncertainty. John McCall, ed. Chicago: University of Chicago Press.

Hall, Robert E. 1988. Financial factors in business fluctuations: commentary. In Financial Market Volatility. Federal Reserve Bank of Kansas City, 73-78.

Hoshi, Takeo, Anil Kashyap, and David Scharfstein, 1989. Bank monitoring and investment: Evidence from the changing structure of Japanese corporate banking relationships. In Asymmetric Information, Corporate Finance, and Investment. R.G. Hubbard, ed. Chicago: University of Chicago Press (forthcoming).

Hubbard, R. Glenn. 1989. Tax corporate cash flow, not income. The Wall Street Journal, February 16.

Institute for Fiscal Studies. 1978. The Structure and Reform of Direct Taxation: London: Allen and Unwin.

Jackson, Thomas H. 1986. The Logic and Limits of Bankruptcy Law. Cambridge: Harvard University Press.

Jensen, Michael C. 1986. Agency costs of free cash flow, corporate finance, and takeovers. American Economic Review 76: 323-29 (May).

Jensen, Michael C. 1988. Takeovers: their causes and consequences. Journal of Economic Perspectives 2: 21-48 (Winter).

Jensen, Michael C. 1989. Active investors, LBOs, and the privatization of bankruptcy. Journal of Applied Corporate Finance 2: 35-44 (Spring).

Jensen, Michael C. and William Meckling. 1976. Theory of the firm: managerial behavior, agency costs, and ownership structure. Journal of Financial Economics 1: 305-60 (October).

Kaufman, Henry. 1986. Debt: the threat to economic and financial stability. In Debt, Financial Stability, and Public Policy. Federal Reserve Bank of Kansas City.

MacKie-Mason, Jeffrey K. 1989. Do firms care who provides their financing? In Asymmetric Information, Corporate Finance, and Investment. R.G. Hubbard, ed. Chicago: University of Chicago Press (forthcoming).

Mayer, Colin. 1989. Financial systems, corporate finance and economic development. In Asymmetric Information, Corporate Finance, and Investment. R.G. Hubbard, ed. Chicago: University of Chicago Press (forthcoming).

Myers, Stewart C. 1977. Determinants of corporate borrowing. Journal of Financial Economics 5: 146-75 (November).

Perry, Kevin and Robert Taggart. 1988. The growing role of junk bonds in corporate finance. Continental Bank Journal of Applied Corporate Finance 1: 37-45 (Spring).

Poterba, James M. 1989. Tax reform and the market for tax-exempt debt. Working Paper No. 2900. National Bureau of Economic Research.

Roe, Mark. 1987. The voting prohibition in bond workouts. The Yale Law Journal 97: 232-79.

Shleifer, Andrei and Robert Vishny. 1988. Value maximization and the acquisition process. Journal of Economic Perspectives 2: 7-20 (Winter).

Shoven, John B. 1987. The tax consequences of share repurchases and other 
non-dividend cash payments to equity owners. In Tax Policy and the Economy, vol. 1, Lawrence H. Summers, ed. Cambridge: MIT Press.

Summers, Lawrence H. 1989. Taxation and corporate debt. Testimony before the Committee on Finance, United States Senate, January 25.

Taggart, Robert A. 1985. Secular patterns in the financing of U.S. corporations. In Corporate Capital Structures in the United States. Benjamin M. Friedman, ed. Chicago: University of Chicago Press.

Tax Analysts. Quantifying the Impact of the Tax Reform Act of 1986 on Effective Corporate Tax Rates.

Warshawsky, Mark. 1988. Pension plans: funding, assets, and regulatory environment. Federal Reserve Bulletin (November). 
